УДК 902.01

https://doi.org/10.24852/2587-6112.2021.3.218.230

\title{
АРХИТЕКТУРНЫЙ ДЕКОР ДРЕВНИХ ТЮРОК ЖЕТЫСУ (VIII-XIII ВВ.)
}

\author{
(C) 2021 г. А.А. Нуржанов
}

В предлагаемой статье описывается архитектурный декор древних тюрок Жетысу на примере средневекового города Кулан. Образование и развитие городов в Средней Азии и на территории Казахстана при всех общих закономерностях имело свои особенности. Этот вывод особенно важен для средневекового Казахстана, где формирование городских центров происходило в условиях исторически сложившегося взаимодействия оседло-земледельческого и кочевого населения, что сказалось на топографии и типах городов, своеобразии городской культуры Резная глина, украшавшая интерьеры монументальных построек в средневековых городах Жетысу (Семиречья), представляет собой уникальный материал. Общепринято считать, что она была способом выражения религиозных, мифологических и, возможно, светских сторон мировоззрения. Для некоторых культур в решении вопросов идеологии и искусства резная глина является одним из основных источников, так как иные источники либо отсутствуют, либо слишком фрагментарны.

Ключевые слова: археология, архитектурный декор, Жетысу, Кулан, зооморфные образы, волк, утка, лань, скульптурные головы.

\section{ARCHITECTURAL DECOR OF THE ANCIENT ZHETYSU TURKS (VIII-XIII CENTURIES)}

\section{A.A. Nurzhanov}

This article describes the architectural decor of Zhetysu ancient Turks (on example of the medieval city-site Kulan).The cities' formation and development in Central Asia and on Kazakhstan territory, with all the general laws, had its own characteristics. This conclusion is especially important for medieval Kazakhstan, where the formation of urban centers took place in the context of the historically established interaction of a sedentary agricultural and nomadic population, which affected the topography and types of cities, the urban culture's originality. Artistic carved clay that adorned the interiors of monumental buildings in the medieval towns of Zhetysu (Semirechye) is a unique material. It is generally accepted that it was used as a way of expressing the religious, mythological and secular worldview aspects. For some cultures, in solving issues of ideology and art, carved clay is one of the main sources, since other sources are either absent or too fragmentary.

Keywords: archaeology, architectural decor, Zhetysu, Kulan, zoomorphic images, wolf, duck, fallow deer, sculpted heads.

Городище Кулан, расположенное у восточного края современного села Кулан на берегу р. Каракат (приток Шу), представляет собой возвышенную площадку почти квадратной формы с крутыми склонами, ориентированную углами по странам света (рис. 1). Площадка с ориентацией на С3-ЮВ размером 214 м, высота - около 7 м. Шахристан со всех сторон окружен земляным валом высотой 0,3-0,5 м. Обнаружены остатки четырех въездов внутрь городища. В северном углу с площадкой на нем, ориентированной, как и шахристан, углами по сторонам света. Высота над окружающей местностью около девяти метров, относительно площадки шахристана - около двух метров. Размер цитадели - 46×46 м. Площадка цитадели со всех сторон окружена земляным валом высотой от 2-2,5 м, по углам расположены остатки четырех башен.

Местность вокруг шахристана на значительное расстояние сильно заболочена, и на ней в разных местах сохранились остатки ранних сооружений в виде крупных земляных холмов-островков, местами сливающихся между собой. Вокруг шахристана сохранились остатки массивного земляного вала шириной у основания 10-15 м, высотой 2,5-5,0 м. В плане вал в форме неправильного пятиугольника размером с севера на юг около 600 метров и с запада на восток около 500 метров. Общая длина вала около 1900 м. Снаружи вала у его основания сохранились остатки рва глубиной 1,6-1,8 м и шириной 7-10 M.

Это городище в конце XIX в. Томашеком, а несколько позднее В.В. Бартольдом было отождествлено с древним городом Кулан (Бартольд, 1963).

Художник С.М. Дудин, участвовавший в экспедиции В.В. Бартольда, писал, что при проезде через Тарты (Кулан) «нельзя не заметить длинного (около полуверсты) невысоко- 


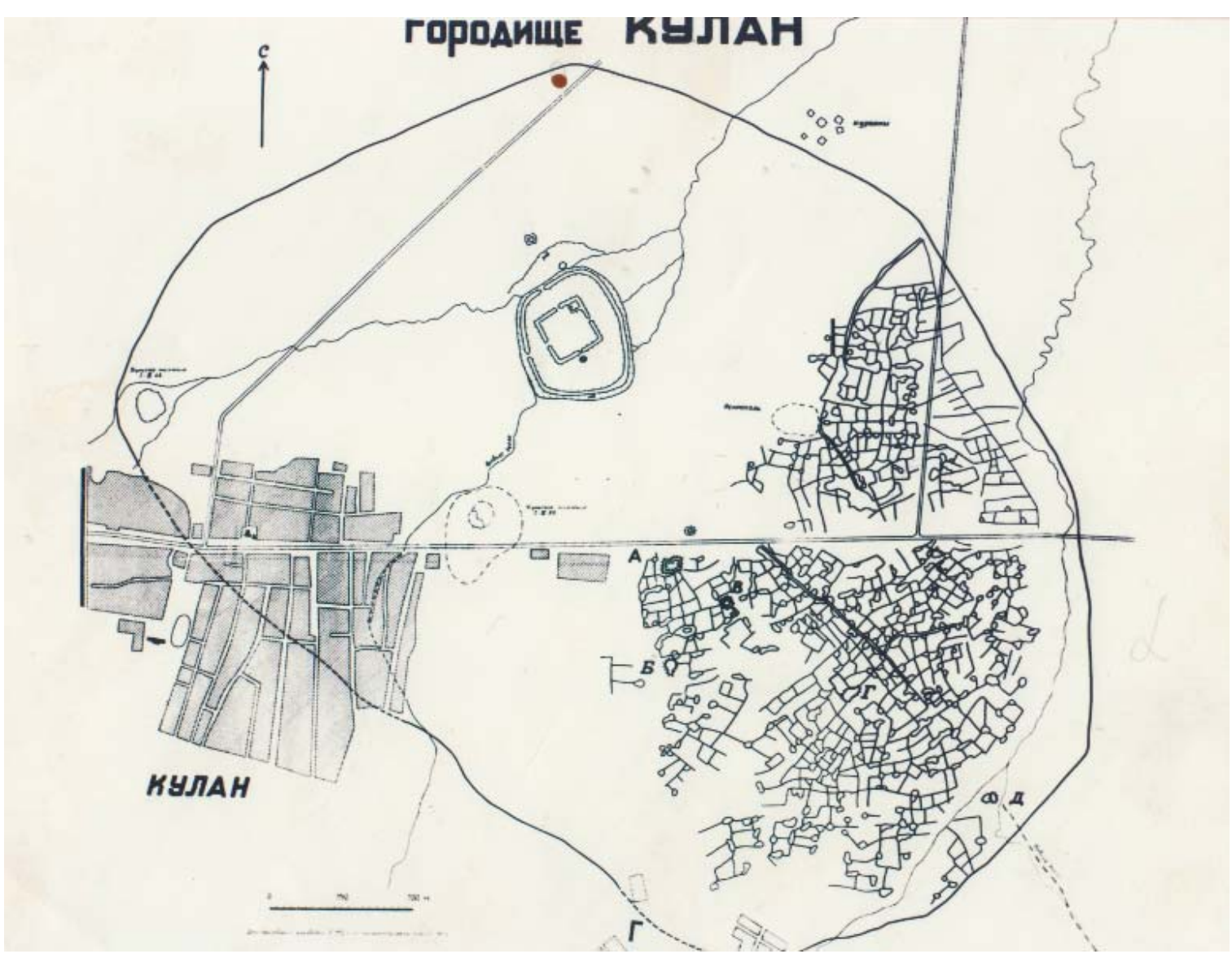

Рис. 1. Топографический план городища Кулан

Fig. 1. Topographic plan of Kulan hillfort

го вала, пересекающего нессколько наискось дорогу и заканчивающегося у большого двухъярусного холма. На восток от деревушки и вала, на расстоянии более версты, встречаются следы второго вала, идущего, по-видимому, параллельно первому» (Бартольд, 1963).

Город Кулан известен в письменных источниках, относящихся к первой половине VII в. В маршрутнике китайского паломника Сюань Цзяня и в истории династии Тан он упомянут под названием Цзюй-лань. Арабские географы ибн-Хордарбех и Кудама помещают Кулан в 14 фарсахах западнее города Тараз. Кудама сообщает, что «песок между Таразом и Куланом с северной стороны, а за ним пустыня из песка и гальки, а в ней ехидны, (она тянется) до границы кимаков» (Волин, 1960). По словам же автора Х в. Ал-Макдиси, «Кулан - укрепленный (город), соборная мечеть в нем (шахристане), он уже опустел, он на большой Таразской дороге» (Волин, 1960). Особый интерес представляет сообщение в анонимном географическом сочинении «Худуд-ал-Алем» (конец X в.), который в числе городов, принадлежащих карлукам, называет город Кулан и сообщает, что «Кулан - маленький округ, граничащий с мусульманами. В нем есть посевы» (Волин,
1960). Из этого сообщения можно заключить, что город в конце X в. принадлежал еще карлукам, что противоречит цитированному выше сообщению Макдиси, который, насколько известно, лично посетил этот город до того, как было сочинено «Худуд-ал-Алем». Автор географического словаря Якут аль Хамави, составивший труд в 20-х гг. XIII в. сообщает: «Кулан - приятный городок на границе тюрков со стороны Мавераннахра» (Волин, 1960).

С Куланом связан ряд известных исторических событий: здесь в 740 г. был убит тюргешским князем Курсулем последний западнотюркский каган Ашина Сынь. В 840 г. до стен Кулана доходили арабские войска (Волин, 1960).

Раскопками объекта «Луговое Г» установлено существование трех разновременных построек. Второй строительный горизонт (рис. 2), датируемый IX-X вв., характеризуется следующими принципами планировочной композиции и особенностями вскрытых раскопками помещений. Ядром комплекса был двор размерами 14,6×12,4 м. В середине двора прослеживается понижение от двух хаузов (водоемов). Центральная часть двора размерами 7,2×6,8 м была вымощена каменными плитами бордового цвета. Из двора имелись 


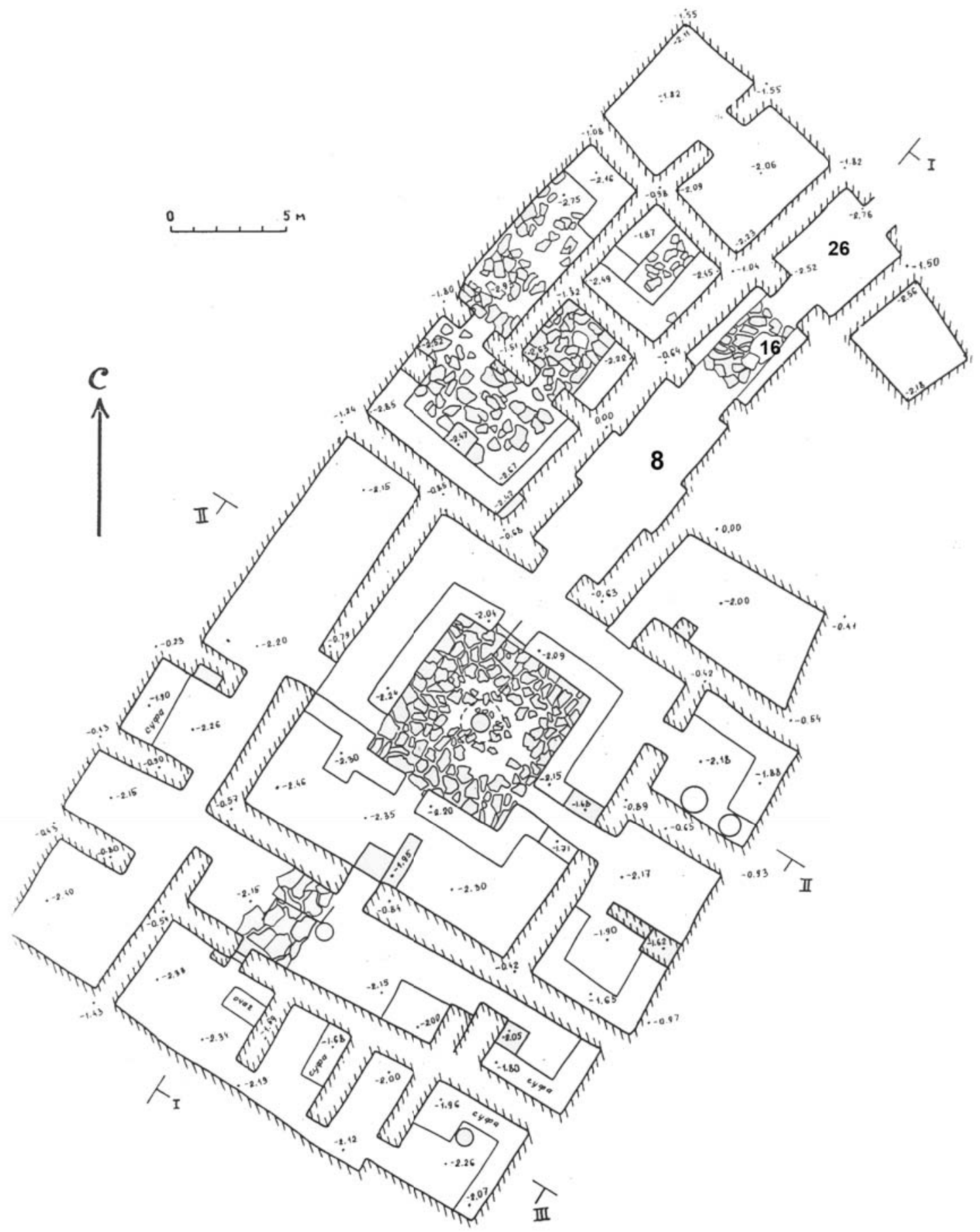

Рис. 2. План 2-ого строительного горизонта дворцового комплекса Кулан

Fig. 2. Plan of the $2^{\text {nd }}$ building horizon of the Kulan palace complex

проходы в ряд помещений. По периметру двор был закрыт навесом, который опирался на колонны, представляя собой четырехсторонний айван. Та часть двора, которая была под навесом, имела суфы высотой до 20-25 см.

Центральный вход в комплексе находился с северо-восточной стороны. Вход представляет собой анфиладу из трех помещений 8 , 16, 26 общей длиной 22,8 м. Все помещения имели перекрытия в виде коробового свода.

Узкое длинное помещение 8 с двумя нишами имеет размеры $3 \times 10$ м. Ширина ниш -2 м, глубина - 0,5 м. Завал помещения 8 состоял из разрушенных сырцовых конструкций перекрытия, глинистого раствора кладки и остатков резной глины. Рисунки на извлеченных из завала фрагментах глины выполнены в технике граффити и глубокой резьбы.

Резная глина как настенный декор средневековых построек уже в раннее Средневековье получает распространение в городах Семиречья (Байпаков, Терновая, 2002).

Однако наибольшего своего развития этот вид декора достигнет в конце X-XI вв. К этому периоду относится и большинство 
обнаруженных в последние годы фрагментов резной глины в Казахстане. Кроме городища Кулан, резьба по сырой глине с цветовым тонированием была встречена в цитадели городища Хамукат, датированного X-XII вв. Новые находки резной глины подтверждают ранее сделанный вывод, что Жетысу, наряду с Согдом, было одной из основных областей распространения этого вида декора в архитектурной практике городов X-XII вв. (Лунина, 1978).

Известные в древности приемы резьбы по высушенной глине с последующим ее обжигом (приемы изготовления посуды, столиков-дастарханов, очажков и т. д.) послужили основой для применения резной терракоты в архитектуре и подготовили почву для расцвета данного вида декоративного искусства. Резная терракота сохранила пластическую гибкость орнамента и глубину резьбы, как в алебастре, и вместе с тем была материалом столь же прочным, как кирпич. Долгое время они сосуществуют и дают одни и те же мотивы орнамента и характер резьбы, иллюстрируя тем самым, что общие художественные вкусы выражались в сходных орнаментальных мотивах независимо от материала, с которым приходилось работать мастерам.

Орнаментальные мотивы в архитектурном убранстве как в росписи, так и в резьбе по ганчу и терракоте встречаются самые разнообразные. Ведущее место среди них занимают «гирихи» - сложные геометрические узоры, требующие от мастера знания геометрии. Растительно-цветочные мотивы также начинают подчиняться линейным построениям и в своей трактовке теряют связь с реальным растительным миром. Излюбленным растительным узором становится цветущий побег «ислими», вводится эпиграфический (буквенный) орнамент. Широкие пояса подписей исполнены почерком «куфи», «насх» и «дивани» в сочетании с растительным орнаментом.

Архитектурный орнамент имеет много общего с мотивами современной ему керамики и узорами тканей, подчеркивая тем самым близость прикладного и монументально-декоративного искусства (Пугаченкова, Ремпель, 1965 , с. 218). Аналогичность орнаментального искусства в керамике, росписи, резном ганче и терракоте дает возможность говорить о единстве художественной культуры Казахстана и Средней Азии. Все вышеперечисленные приемы архитектурного декора как бы суммируют достижения средневековых мастеров, художественную культуру в целом как высшее проявление духовной культуры городских жителей Юго-Восточного Казахстана X-XIII вв.

Резная глина, украшавшая интерьер монументальных построек в средневековых городах Юго-Восточного Казахстана, представляет собой уникальный материал. Мастера-резчики передали особенности художественного языка Средних веков. Археологические и письменные источники подтверждают синкретический характер материальной и духовной культуры Жетысу VIII-XIII вв., сложившейся здесь в период господства тюрков и карлуков VII-IX вв.

Наиболее яркие материалы были получены при раскопках группы помещений входного комплекса городища Кулан. Он находится на северо-восточной стороне и делит восточную часть постройки на две части по оси югозапад - северо-восток, упираясь во двор. Вход представлен тремя помещениями (№ 26, 16, 8) общей длиной 22,8 м. Все помещения имели перекрытия в виде коробового свода. Завал помещения № 8 состоит из разрушенных сырцовых конструкций перекрытия, глиняного раствора кладки и остатков резной глины. Толщина его составляет 79-80 см. Фрагменты резной глины располагались по всей площади помещения, не ниже 15-20 см от пола. Рисунки на извлеченных из завала фрагментах резной глины по технике исполнения делятся на граффити и глубокую резьбу.

Две арочные панели с двусторонней орнаментацией были расположены параллельно стенам с входными проемами. Относительно ниши арочные панели располагались слева и справа на расстоянии, равном примерно 1 м, образуя в центре удлиненного помещения № 8 пространство, по форме приближающееся к квадрату. Внутри этого пространства вдоль стен с нишами были размещены две суфы (рис. 3). Ширина одной суфы - 1,1 м (со стороны северо-западной стены) и другой $-0,76$ м (со стороны юго-восточной). Панели арочной формы с двусторонней орнаментацией, расположенные слева и справа относительно ниши, с учетом украшающей их резьбы предположительно имели толщину до 30 см. Плита арочных очертаний, находящаяся в юго-западной части помещения, найдена на расстоянии 180 см от стены, противоположной входу в помещение.

К кругу, расположенному в центре плиты, слева и справа примыкает растительный орнамент, выполненный в технике граффити. Орнамент представляет собой спирально закру- 


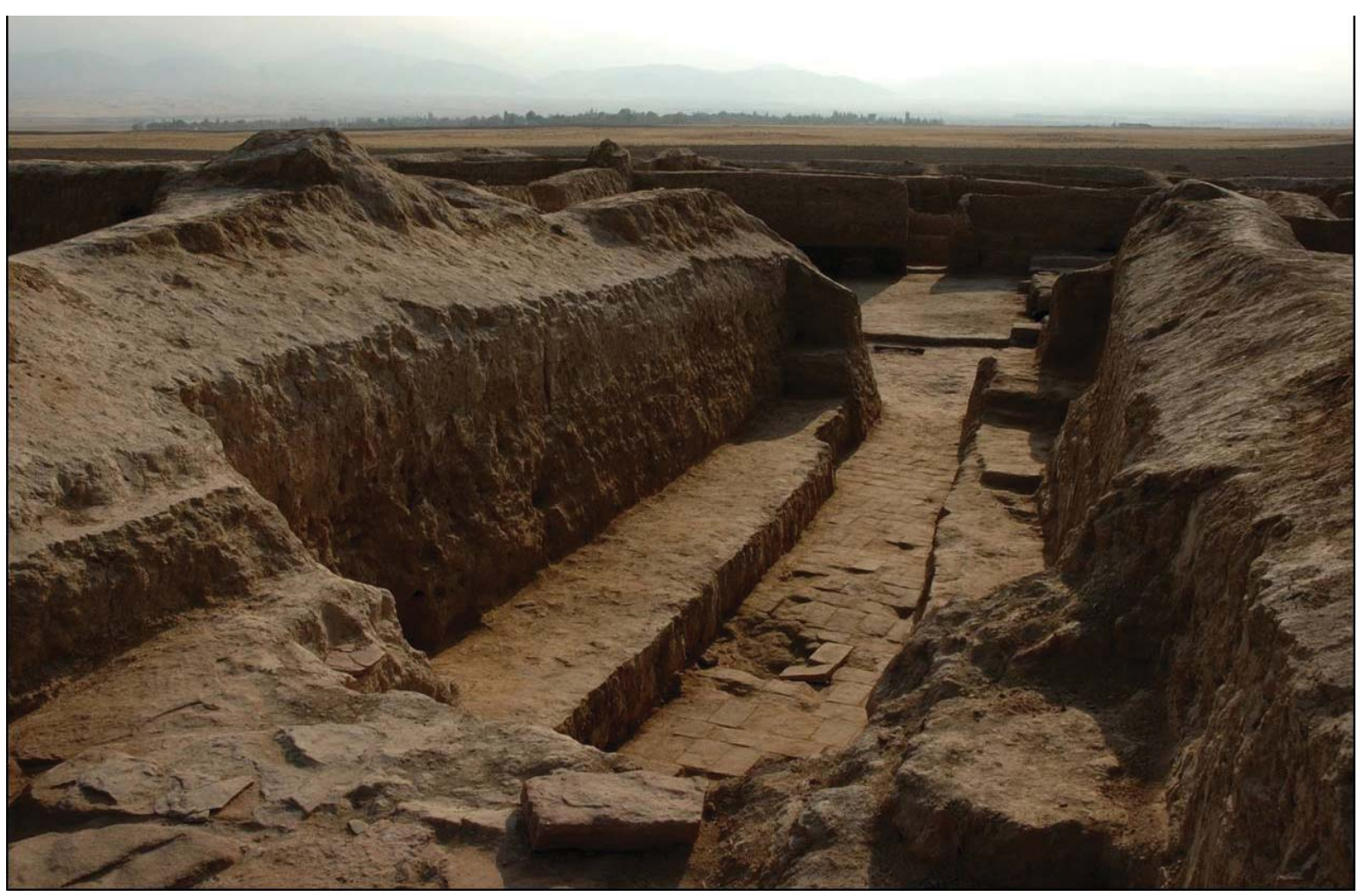

Рис. 3. Две суфы

Fig. 3. Two sufas

ченные стебли побега «ислими» с завитками диаметром 9-12 см. Один из концов лепестка «ислими» острый, отогнутый, другой - тупой, обрезанный.

Слева от центрального круга на расстоянии 43-44 см среди завитков «ислими» помещено изображение пасущейся лани, выполненное в технике граффити. В длину изображение лани составляет 22 см, в высоту - 14 см. Лань, развернутая в противоположную сторону от центра, опустившая голову, прикоснулась мордочкой к завитку «ислими». Животное стоит на тонких ножках с копытами. Задняя нога отставлена и согнута в колене. У лани загнутый вверх хвостик, острые ушки, на мордочке обозначен удлиненный глаз. По низу туловища проходит полоса с вертикальными наклонными насечками, вероятно, изображающими шерсть животного. Лань находится в левой части композиции и развернута в сторону юго-восточной стены (рис. 4).

В сочинении «Тай-пин гуан чжи» coхранилась версия легенды об ином первопредке тюрков, антиподе волка - белом олене с золотыми рогами. Во время охоты этот олень был убит одним из предводителей племени аши. Правитель Имо-шэли приказал казнить виновного. Позже, во время жертвоприношений знамени с изображением волка, в церемонии участвовали и представители племени аши, предок которого убил оленя (Кычанов, 1997).
Основным героем данного предания является олень с золотыми рогами, с образом которого связано происхождение династийных тюрков. Олень обитает в пещере предков, на него наложено табу. Начало легенды дает основание считать, что речь идет не просто об олене, а о лани - прародительнице, духе земли и леса, противостоящей духу воды (Зуев, 1967).

Под образом зверя, определённого божества-тотема, прячется древний этнос - племя. Образ оленя (лани) был в качестве почитаемого божества у древних саков-скифов, о чем свидетельствуют находки многочисленных «оленных камней» от Причерноморья до Монголии (Ушницкий, 2016).

Тюрки-ашина поклонялись оленю как священному животному - он был табуирован. По словам Ю.А. Зуева, олень был не только священным, но и отождествлялся с племенем Ашина (Зуев, 1967).

Следующая орнаментация представлена полосой-сеткой ромбов с треугольниками внутри. Верхний ряд ромбов образован продолжением линий каплеобразных элементов, нижний ряд служит началом формирования орнаментальной полосы, расположенной ближе к центру. Полоса состоит из «сердечек», которые, накладываясь друг на друга, образуют петли. От углов ромбов к центру «сердечек» опускаются бутоны-трилистники. 


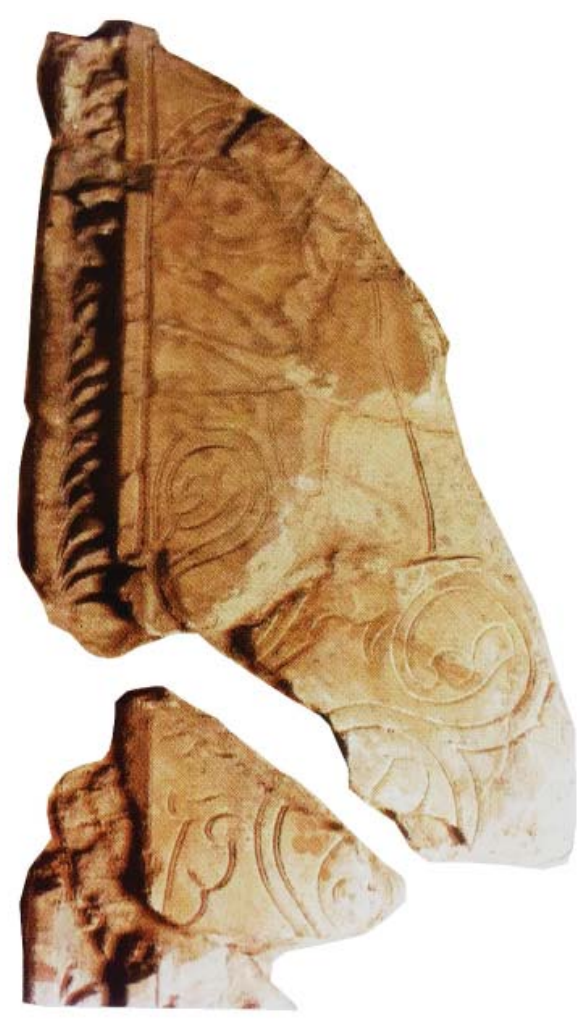

Рис. 4. Изображение лани (оленя) Fig. 4. Image of a doe (deer)

Продолжение дуг, образующих «сердечки», формирует новый ряд ромбов с треугольниками внутри. Из центрального орнамента сохранились петлеобразный орнамент и бутон трилистник.

В крайней правой части композиции, изображенной на этой стороне арочной плиты, сохранился нижний прямоугольный фрагмент рамки прямой гладкой полосы шириной 1,5 см. На фрагменте с рамкой среди завитков «ислими» изображен волк высотой 16 см с раскрытой зубастой пастью, острыми ушами и узким хищным глазом. От изображения волка сохранился лишь фрагмент с передней части туловища. Животное развернуто в сторону юго-восточной стены. Изображения волка и побегов «ислими» выполнены в технике граффити (рис. 5).

Образ волка является одним из наиболее значимых животных символов разных народов мира. Во многих культурах он играет особую роль, имеет огромное культовое, ритуальное и социальное значение.

В мифах, фольклоре и волшебных сказках волк олицетворяет свирепость, коварство, жестокость, зло, но также храбрость и победу. Кроме того, при определенных обстоятельствах волк мог стать могучим защитником беспомощных созданий. Общим для многих мифологий Евразии является сюжет о воспи-

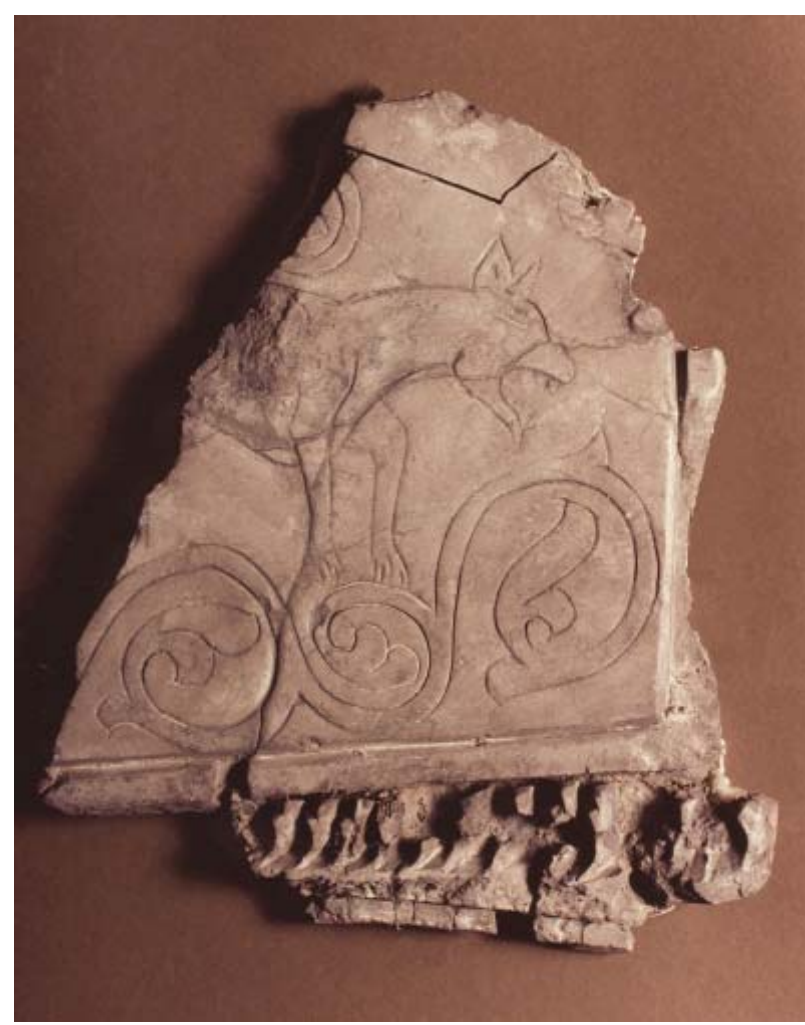

Рис. 5. Изображение волка в стиле граффити Fig. 5. Wolf's image, graffiti style

тании родоначальника племени (а иногда и его близнеца) волчицей. Известно множество историй о волках-прародителях; римская легенда о капитолийской волчице, вскормившей Ромула и Рема; древнеиранская - о волчице, вскормившей Кира и т. д. (Нуржанов, 2016).

Наибольший интерес представляет изображение волка в тюркскую эпоху, когда каждое изображение можно трактовать, опираясь на материальные и письменные источники того периода. Так, древнетюркскую генеалогическую легенду о происхождении правящего дома Ашина иллюстрирует единственный пока эпиграфический памятник начального периода существования Тюркского каганата - стела с согдоязычной надписью (Бугутская надпись). В навершии стелы барельефа изображена волчица, под брюхом которой человеческая фигурка с отрубленными руками и ногами.

Внимание многих ученных привлекла легенда о происхождении алтайских тюрок: «Среди нескольких легенд о происхождении тюрок туг-ю, записанных в китайскую летопись, одна особенно ценна. Сообщив, что «в 40-х годах V века туг-ю жили на Южном Алтае и добывали железо для жуаньжуаней, китайский историк передает версию о том, что туг-ю происходят из племени со, 


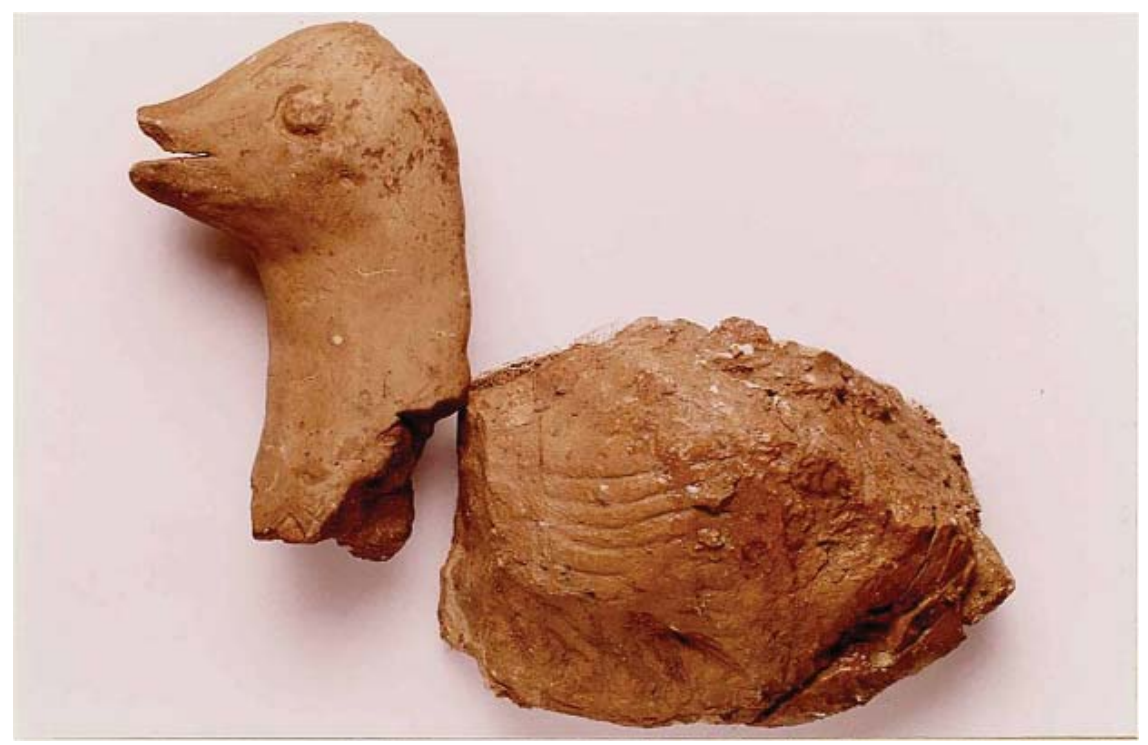

Рис. 6. Терракотовая утка-гусь

Fig. 6. Terracotta duck-goose

обитавшего некогда на север от хунну. Первоначально их было 70 братьев, старший из них Нишиду родился от волчицы» (Киселев, 1949).

Высокий статус волка в традиционных представлениях обусловливает его важную роль в охранительной магии (Иванова, 2012). Наиболее распространенным способом охраны ребенка является наречение волчьими именами: Курт (волк), Бёрю (волк), Кызылкурт (красный волк), Бозкурт (серый волк), Бёрюджан (волк-душа), Бёрюхан (волк-хан), Куртдемир (волк-железо) (Kalafat, 1995; Yazıcı).

Сошедшего с ума ребенка для излечения проводят под волчьим черепом или челюстью. Та же процедура проводится для продления ребенку жизни (Beydili, 2005).

Участвует волчий череп, а также волчий глаз и во время празднования сороковин их держат над ребенком в бане во время проведения обрядов (Серебрякова, 1992). Для охраны ребенка в семье, где часто умирают дети, новорожденного протаскивают сквозь отверстие в волчьей шкуре на месте пасти или через растянутую пасть (Серебрякова, 1980; Серебрякова, 1992).

Поскольку волк считается главным защитником, волчьи зубы (в основном клыки), когти, кости, глаза и кусочки шкуры, вырезанные со спины, широко применяются в качестве оберега от сглаза (назарлык). Обычно их носят при себе, в кармане или на шее, кладут под подушку или подвешивают к колыбели (Гордлевский, 1962; Льюис, 2004, с. 110; Серебрякова, 1992; Araz, 1995; Beydili, 2005, c. 111, 352-353; Erbek, 2002; Kalafat, 1995).
На основе изучения истоков широко распространенного у тюрко-монгольских народов игрища көк-бури (көкпар) С.П. Толстов приходит к выводу, что своими корнями оно восходит к тотемно-свадебнему ритуалу, где олицетворением мужского тотема являлся волк, а женского - козел (Толстов, 1935).

В этой связи следует указать на то, что киргизы до сего времени считают целебным мясо козла, туша которого служит объектом спортивного состязания көк-бури. Поэтому сразу же после того, как туша-козла брошена победителем возле одной из юрт, ее разделывают на куски и раздают всем желающим. Те, кому мясо козла не досталось, не считают зазорным зайти в юрту и выпить бульон. Этот обычай - не что иное, как отголосок причащения к тотему (Баялиева, 1972).

Широкое распространение зооморфных образов, в том числе и образа волка, в раннем искусстве кочевников Евразии не случайно, оно характеризует определенную стадию развития мировосприятия. Рассмотрев разные аспекты религиозных представлений, касающихся образа волка, можно утверждать, что в их основе лежит первоначальная сакрализация этого образа, основывающаяся на совокупности природных характеристик реального животного - волка.

Внутри юго-восточной ниши глубокой резьбой было изображено плодоносящее дерево. На вершине дерева когда-то располагались две глиняные скульптуры, изображающие уток, которые крепились головами к верхнему изгибу арки. Сохранилась фигура утки $(19 \times 17$ см), развернутая влево, 
которая собирается из двух фрагментов (рис. 6).

B VI-VII вв. птицы - утка, гусь, фазан украшают настенную роспись (Пенджикент), ткани, металл. С ними связано представление о потустороннем мире, куда душа умершего якобы улетает птицей.

Образ водоплавающих птиц часто встречается в фольклоре северных алтайцев. В алтайском героическом эпосе «Кан-Дьелбекей» мотив героического сватовства устойчиво связывается с гусем. Сюжетный блок классифицируется как «жена - лебедь/гусь». Здесь речь может идти об экзогамном дуализме. Брак с женщиной-гусем является более предпочтительным, чем брак с женщиной из подземного мира, т. е. по мере развития эпоса акцентируется социальная значимость данного кода. Моделирующая роль водоплавающих птиц в космогонических мифах не вызывает сомнений. В эпосе лебедю, как и гусям, отводится роль гонцов, медиаторов, доставляющих «ханские грамоты», «божьи грамоты». В сказании «Алып-Манаш» в исполнении Натальи Павловны Черноевой четко прослеживается роль птиц в качестве гонцов (Шинжин, 1997). Примечателен тот факт, что в мифологии некоторых народов Сибири и Дальнего Востока творцами мира выступает лебедь. Так, например, В.В. Радловым был записан миф у северных алтайцев (чалканский) о сотворении мира (Радлов, 1989). У нанайцев лебедь создал нанайскую землю. По мифологии коми мир был создан гагарой, доставшей землю из-под воды (тоже у ненцев, кетов, обских угров, эвенков и др.) (Тучкова, 2005). В сказаниях лебедь и гусь являются положительными персонажами. Так, в героическом сказании, записанном от народного сказителя Николая Улагашева «МалчиМерген», приводится песня о восхвалении серого гуся (Героические сказания, 1961). В фольклоре ряда тюркских народов журавль, лебедь считаются священными птицами и их нельзя убивать (Кучукова, 2013).

У тюркских народов и другие водоплавающие птицы (утка, гусь) входят в число особо почитаемых. В широком смысле они символ единства, союза между землей, водой и небом. В эпосе и мифах это часто встречающиеся образы. К примеру, в алтайских сказаниях серый гусь - помощник и друг богатыря, который поет ей хвалу? «Добрая птица гусь! / Неустанны крылья твои, / По воде ты как цветок плывешь, / По земле ты легче иноходца ходишь. / Вокруг Алтая облетишь - / Уста- лости не почувствуешь, / Вокруг земли облететь / Сил у тебя хватит» (Улагашев, 1941). В тувинских эпических сказаниях фигурирует одеяние из птичьего оперения как вариант оборотничества героя и возможность проникновения в Верхний мир.

Удивительно, но утка-гусь-лебедь, которым подвластны две сферы - водная и небесная, в одном из сказаний участвуют в цепочке перевоплощений (оборотничества) героя в подземном мире: утка с золотой шеей - турпан с золотой шеей - гусь златоглавый - лебедь желтопестрый (Орус-оол, 2001). Кроме того, в алтайском мифе доброе божество Ульгень представлялся в виде светлого гуся или утки. Сюжет об утке как птице-демиурге сохранился в хакасском фольклоре у качинцев (подробно о божественных птицах и птицах, с которыми тюрки связывали свое происхождение). Сюжет этот известен в мифах многих сибирских народов (Король, 2015).

В помещении № 8 скульптурные остатки и куски плиты с рельефом были сконцентрированы в центральной части перед нишами среди упавшей резной штукатурки, датируемой началом XI в. Появление рельефа скульптуры в здании верхнего строительного горизонта относится к наиболее раннему этапу его существования, к IX в. (если, конечно, статуи не были перемещены из помещений нижележащих слоев, датируемых VII-VIII вв.) Видимо, статуи и рельефное панно располагались в глубине стенных ниш, заложенных впоследствии при реконструкции кирпичом. Поэтому при разрушении перекрытия и стен помещения разновременное оформление интерьера оказалось в одном уровне.

Материалом рельефов и скульптуры служил плотный тонко отмученный темнокоричневый лесс, обладающий хорошими пластическими свойствами. Отдельные части скульптур и рельефы окрашены по поверхности непосредственно по глине, скульптурные головки по слою белой подгрунтовки. Большое место в окраске занимает розово-красный цвет, которым были покрыты элементы рельефной композиции и одежда персонажей. Черным цветом окрашены волосы, подведены глаза, брови, очерчены детали одежды.

Среди находок скульптуры - четыре головы, отбитые от торсов, торс человека в облегающей одежде (кафтане), глухо застегнутой у ушей, с отбитыми руками и ногами, верхняя часть такого же по размерам и оформлению торса, часть шеи и плечи (рис. 7). 

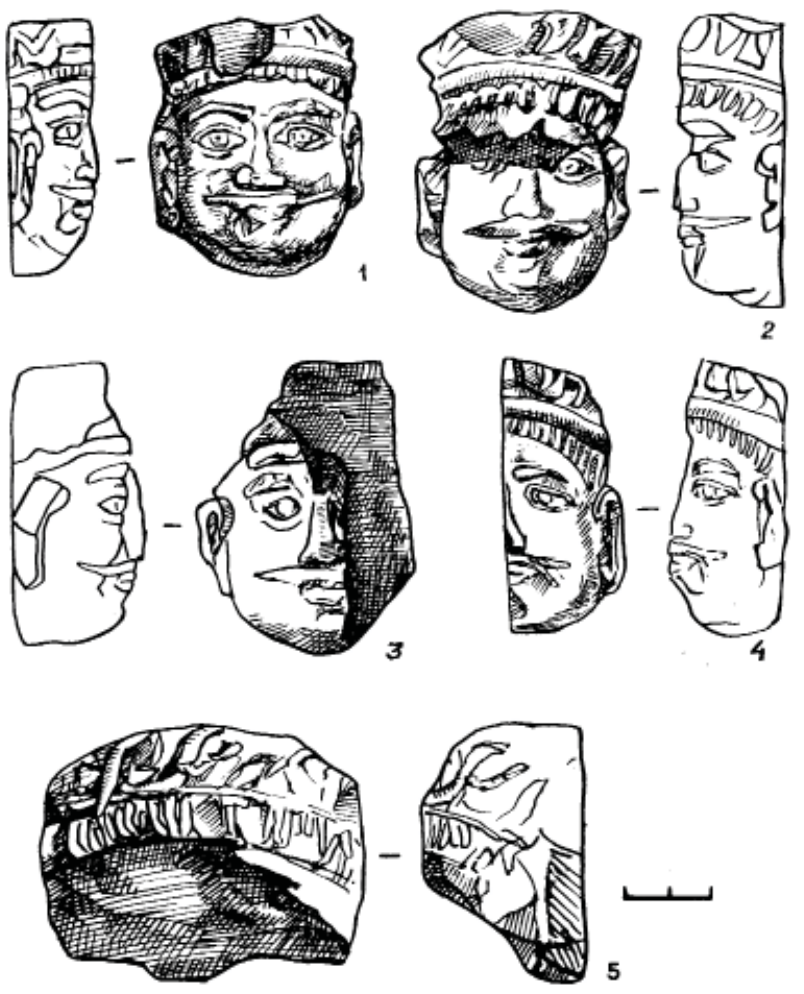

Рис. 7. Скульптурные головы

Fig. 7. Sculptured heads

Статуи были выполнены в полный рост, судя по размерам голов $(6,7-8$ см по высоте, 5 см в ширину). Три скульптурные головки даны в анфас, одна в профиль. Статуи пристенные, выполнены в полном объеме, но без проработки тыльной стороны. Закрепление скульптуры к стене обеспечивалось силой сцепления глины (Нуржанов, 2003).

Первый персонаж - мужчина зрелого возраста с полным, почти круглым лицом, упитанными щеками, округлым подбородком. Большие, открытые, слегка навыкате глаза оконтурены рельефным валиком век. Радужная оболочка и зрачки выделены краской, нанесенной на белую подгрунтовку. Полукруглые брови почти сходятся на переносице, нос умеренный, прямой, с широкими краями. Усы и борода такие же, как и у вышеописанной скульптуры. Схематично показанные уши открыты, над ушами пряди волос. На голове корона из двух ободков и невысокой расширяющейся кверху тульи. Нижний ободок разработан выпуклой поперечной насечкой, верхний - гладкий, цилиндрической формы. Верхняя часть короны в плохой сохранности. Заметно, что она имела ряд зубцов, из которых сохранились только три с левого края (рис. 7: 1).

Вторая скульптурная голова повреждена трещиной, проходящей через переносицу от виска до виска. Волевое лицо подквадратного очерка принадлежит молодому мужчине. Черты лица симметричны. Большие открытые глаза с рельефно-моделированными веками, без эпикантуса (монголоидной складки), прямой нос, широкий подбородок с клиновидной бородкой над красиво очерченными губами, длинные волосы коротко отстрижены и убраны назад, открывая лоб и уши. Слегка отогнутые в форме усы. Крупные ушные раковины разработаны схематично. В мочке левого уха видно отверстие для серьги. На голове корона в виде ободков и невысокой, расширяющейся кверху тульи. Нижний ободок убран перлами, верхний выпуклый гладкий. Завершение короны представляет ряд округлых, выпуклой формы зубцов (рис. 7: 2).

Одна из скульптурных головок представляет портрет юноши со смешанными чертами европеоидно-тюркского типа. Голова юноши; сохранилась правая половина лица широкого овального очерка. Глаза миндалевидные, веки набухшие с оттянутым вниз наружным краем, нос с горбинкой, узкий у переносицы с широкими крыльями, над полными губами прямые длинные усы, продолжающиеся до середины щек. Подбородок - слегка выступающий вперед скругленного очертания. Большая часть лба, прическа и головной убор утрачены. Крупные раковины ушей открыты. Просматривается часть налобной повязки или ободка короны (рис. 7: 3).

Четвертая головка - профильное изображение мужчины, развернутое влево. Высота головки - $6 \mathrm{~cm}$, расстояние от среза затылочной части до кончика носа 3 см. Головка срезана с двух сторон. Глаз у изображенного мужчины миндалевидный со слабо выделенной радужкой, угол глаза срезан, опущен вниз, придавая лицу выражение грусти. Широкая бровь и горизонтально расположенный ус также опущены вниз. В ухе изображена серьга, на лбу - челка из прямых волос. Ободок головного убора широкий, под ним - складки или зубцы. Головные уборы имеют сходство с головными уборами, венчающими головы мужчины и женщины из юго-восточной ниши (рис. 7: 4).

Композиция из этих скульптур, по-видимому, представляла династийный портрет, который утвердился в Средней Азии в первые века нашей эры (Ремпель, 1989). Скульптурные головы представляют владетельных особ, которые явно отнятся к единой родоплеменной группе с ярко выраженными признаками этнической 
общности. Скорее всего, это представители местной династической ветви - главные члены династии. Об этом свидетельствуют короны, которыми увенчаны головы персонажей, а также спокойное величавое выражение лиц, полное привычного достоинства (рис. 7: 5).

Тема прославления царя имеет глубокие традиции в искусстве Древнего Востока. Она была коронной в ахеменидском монументальном искусстве (персепольские рельефы), прошла через династическую тему в искусстве во время греческой эллинизации азиатского Востока (царские портреты селевкидской Сирии и Греко-Бактрии), проявилась в смыкании династической темы с культом предков в Кушанской Бактрии (Халчаян, Дальверзинтепе, Сурк-Котал), представлена в монументальной скульптуре Хорезма II-III вв. н. э. в зале царей на Топраккале.

Сохранившиеся лица скульптурных голов из «Лугового Г», при явной этнической и типологической общности, индивидуальны. Подчеркивая их принадлежность к какойто единой родовой группе, ваятель вместе с тем выделяет характерные для каждого особенности и отличия. Портретность лиц выражена тонкими отличиями черт, передачей полноты или худобы лица, приметами возраста. Сквозь внешнюю личину не проступает нравственная характеристика, но это не застывшие маски - в каждом лице запечатлено определенное выражение. Глаза под сильно рельефными веками, обощенная пластика форм - все это передает ощущение напряженности духовной жизни, скрытой под внешней личиной.

Но вряд ли можно считать эти портреты личными, существующими в форме личного реалистического сходства или приближения к оригиналу. Они имперсональны, то есть созданы на основе обобщения. Все эти портретные изображения одного типа, в которых «род» предстает в индивидуальных (хотя и типированных) чертах. Уже на античном этапе истории имело сосуществование в портрете индивидуальных черт с выработкой идеального. Как замечено крупнейшим авторитетом в этой области Л.И. Ремпелем, «имперсональные» портреты
Древнего Востока вообще не ставили своей целью персонального сходства с натурой (Ремпель, 1989).

Облик тюрков известен по каменным изваяниям, гравировке на костяной пластинке из могильника Чир Юрт (Дагестан), живописи Афрасиаба, аверсам монет, парадной серебряной посуде. На изображениях лица монголоидного типа: раскосые небольшие глаза, маленький рот, обрамленный вислыми усами. Волосы зачесаны назад, заплетены в несколько косичек (от 4 до 9), в ухе серьга. Одежда состоит из длиннополого облегающего кафтана с треугольными отворотами и узкими рукавами. В талии кафтан стягивался ремнем или нарядным поясом с набором блях. Головные уборы представляли собой шлемышишаки, шлемы-«мисюрки» с мысиком над переносицей, малахаи. В одном из погребений Кочкорской долины найден головной убор из ткани в виде башлыка (История Киргизской CСР, 1984. С. 321-324.).

Аналогии штуковой резьбы разнообразны и широки. Это известные памятники Средней Азии и памятники Ближнего Востока, как например, Самарра, Фускат, Мшатта. Искусство резьбы по штуку, безусловно, распространялось по Великому шелковому пути и связывало культуры разных стран и народов.

Архитектурный декор Средних веков через орнамент отражает эстетические воззрения эпохи, но критерий его художественности сложен и неоднозначен для разных типов. В живописи оценивается идея и уровень его исполнения (через индивидуальное восприятие): произведение архитектурной детали - панно, колонны, декорированного портала и т. д., оценивается с позиций целесообразности их сооружения, идейно-образного соответствия целому и т. д. Поэтому в архитектуре и монументально-декоративном искусстве эстетические качества могут быть искусственно выделены из определенного стиля художественной культуры своей эпохи. Стиль архитектурной орнаментики Средней Азии и Казахстана X-XII вв. рассматривается «как новаторский стиль, как обобщение вековой практики народа, вступившего на новый этап своего социального и культурного развития».

\section{ЛИТЕРАТУРА}

Байпаков К.М., Терновая Г.А. Архитектурные особенности, декор и культовая принадлежность некоторых помещений дворцового комплекса города Джамукат // Изв. МОН РК НАН РК. Серия общ. наук. 2002. № 1. С. 219-222. 
Бартольд В.В. Отчет о поездке в Среднюю Азию с научной целью. 1893-1894 гг. // Сочинения. T. IV. М.: Наука, 1963. С. 21-91.

Бартольд В.В. Очерк Семиречья // Сочинения. Т. ІІ. Ч. І. М.: Изд-во восточной литературы, 1963. C. $23-108$.

Бартольд В.В. К вопросу об оссуариях Туркестанского Края // Сочинения. T. IV. М.: Наука, 1966. C. $154-171$.

Баялиева Т.Д. Доисламские верования и их пережитки у киргизов. Фрунзе: Илим, 1972. 170 с.

Волин С.Л. Сведения арабских источников IX-XVI вв. о долине реки Талас и смежных районах // Труды Института истории, археологии и этнографии. T. VIII. Алмат-Ата: изд-во Академии наук Казахской ССР, 1960. С. 72-92.

Героические сказания, записанные от народного сказителя Н.У. Улагашева / Ред. А. Коптелов. Горно-Алтайск: Горно-Алтайское книжное издательство, 1961. 222 с.

Гордлевский В.А. Из османской демонологии // Избранные сочинения. Т. III. История и культура. М.: Восточная литература, 1962. С. 299-325.

Зуев Ю.А. Древнетюркские генеалогические предания как источник по ранней истории тюрков. Дисс. ...канд.ист.наук. Алма-Ата, 1967. 200 с.

Иванова В.В. Волк охраняющий и волк нападающий // Бестиарий II. Зооморфизмы Азии: движение во времени / Отв. ред. М. А. Родионов. РАН. Санкт-Петербург: Музей антропологии и этнографии им. Петра Великого (Кунсткамера), 2012. С. 91-98.

История Киргизской ССР. Т.1. С древнейших времен до середины ХІХ в. / Гл. ред. В.М. Плоских. Фрунзе: Кыргызстан. 1984. 798 с.

Киселев С.В. Древняя история Южной Сибири / МИА. № 9. Л.: АН СССР, 1949. 364 с.

Король Г.Г. Мотивы летящей птицы и крылатой богиги в средневековой торевтике и традиционное наследие народов Саяно-Алтая // Мировоззрение населения Южной Сибири и Центральной Азии в исторической ретроспективе. Вып. VIII. / Отв. ред. П.К. Дашковский. Барнаул: АлтГУ, 2015. С. 47-63.

Кучукова Д.А. Зооморфные образы в мифологии северных алтайцев: к проблеме этнокультурных контактов народов Сибири // Вестник Тюменского государственного университета. 2013. № 2. С. 21-26. $320 \mathrm{c}$.

Кычанов Е.И. Кочевые государства от гуннов до маньчжуров. М.: Восточная литература РАН, 1997.

Лунина С.Б. Резная глина в Средней Азии // История и археология Средней Азии / Ред. О.В. Обельченко, Д.М. Овезов, Т. Ходжаниязов. Ашхабад: Ылым, 1978. С. 203-211.

Льюис Р. Османская Турция. Быт. Религия. Культура. М.: Центрполиграф, 2004. 239 с.

Нуржанов А.А. О культе волка в традициях народов Евразии // Культурное наследие Евразии (с древности до наших дней) / Отв. ред. Б.А. Байтанаев. Алматы: Институт археологии, 2016. С. $216-227$.

Нуржсанов А.A. Терракотовые персонажи из городища Кулан // Вестник Казахского государственного университета им. аль-Фараби. Серия историческая. 2003. №2 (29). С. 115-118.

Орус-оол С.М. Тувинские героические сказания (текстология, поэтика, стиль). М.: МАКС Пресс, 2001. $424 \mathrm{c}$.

Пугаченкова Г.Н., Ремпель Л.И. История искусств Узбекистана с древнейших времен до середины ХІХ в. М.: Искусство. 1965.688 с.

Радлов В.В. Из Сибири. М.: Наука, 1989. 718 с.

Ремпель Л.И. Архитектурный орнамент Узбекистана: история развития и теория построения. Ташкент: Изд-во худ. лит. Уз ССР, 1961. 606 с.

Ремпель Л.И. Портрет в искусстве античной Средней Азии // Античные и раннесредневековые древности южного Узбекистана. В свете новых открытий Узбекистанской искусствоведческой экспедиции / Отв. ред. Г. А. Пугаченкова. Ташкент: «Фан» Узбекской ССР, 1989. С. 111-131.

Серебрякова M.Н. К вопросу об истоках и эволюции традиционного мировоззрения турок // Традиционное мировоззрение народов Передней Азии / Отв. ред. М. А. Родионов, М. Н. Серебрякова. М.: Наука, 1992. С. 61-94.

Серебрякова М.Н. О некоторых представлениях, связанных с семейно-обрядовой практикой сельских турок // Символика культов и ритуалов народов зарубежной Азии / Ред. Жуковская Н. Л., Страганович Г.Г. М.: Наука, 1980. С. 165-177.

Толстов С.П. Пережитки тотемизма и дуальной организации у туркмен // Проблемы истории докапиталистических обществ. 1935. №9-10. С. 3-41. 
Тучкова Н.А. Гл. 7. Мировоззрение. Мифология. Культ // Народы Западной Сибири. Ханты. Манси. Селькупы. Ненцы. Энцы. Нганасаны. Кеты / Отв. ред. И. Н. Гемуев, В. И. Молодин, 3. П. Соколова. М.: Наука, 2005. С. 368-377.

Улагашев Н.У. Алтай-Бучай. Ойротский народный эпос. Новосибирск. 1941. 407 с.

Уиницкий B.B. Генеалогические легенды древних тюрков-ашина: волчица и олень-лань в образе тотемных предков // Проблемы востоковедения, 2016. № 3 (73). С. 30-35.

Шинжин И.Б. Тропой, проложенной веками: жизнь и творчество сказительницы Н.П. Черноевой. Горно-Алтайск: ГАИТИ. 1997. 20 с.

Araz R. Harput'ta eski türk inançları ve halk hekimliği. Ankara, 1995.

Beydili C. Türk Mitolojisi Ansiklopedik Sözlük. Ankara, 2005. C. 352-353.

Erbek M. Çatalhöyük’ten günümüze Anadolu motifleri. Ankara, 2002.

Kalafat Y. Doğu Anadolu'da eski Türk inançlarının izleri. Ankara, 1995. C. 98.

Yazıcı K. Kurt dede kavramının tarihi ve kültürümüz içindeki yeri. URL: http://www.gulenkoyu.com/ forum/index.php?topic=2364.0;wap2 (дата обращения: 15.09.2011).

\section{Информация об авторе:}

Нуржанов Арнабай Абишевич, кандидат исторических наук, главный научный сотрудник, Институт археологии им. А.Х. Маргулана КН МОН РК (г. Алматы, Казахстан).

\section{REFERENCES}

Baipakov, K. M., Ternova, G. A. 2002. In Izvestiia MON RK, NAN RK, seriia obshchestvennykh nauk (Bulletin of the Ministry of Education and Science of the Republic of Kazakhstan and the National Academy of Sciences of the Republic of Kazakhstan, Social Sciences Series) (1), 219-222 (in Russian).

Bartol'd, V. V. 1963. In Sochineniia (Works) 2 (1). Moscow: "Vostochnaia literatura" Publ., 23-108 (in Russian).

Bartol'd, V. V. 1966. In Sochineniia (Works) 4. Moscow: "Nauka" Publ., 21-91 (in Russian).

Bartol'd, V. V. 1966. In Sochineniia (Works) 4. Moscow: "Nauka” Publ., 154-171 (in Russian).

Baialieva, T. D. 1972. Doislamskie verovaniia i ikh perezhitki u kirgizov (Pre-Islamic Beliefs and their Vestiges among the Kyrgyz people). Frunze: "Ilim" Publ. (in Russian).

Volin, S. L. 1960. In Trudy instituta istorii, arkheologii i etnografii (Proceedings of the Institute for History, Archaeology and Ethnography) VIII. Alma-Ata: Academy of Sciences of the Kazakh SSR, 72-92 (in Russian).

Koptelov, A. 1961. (ed.). Geroicheskie skazaniia, zapisannye ot narodnogo skazitelia N.U. Ulagasheva (Heroic Legends Narrated by the Folk Storyteller N.Yu. Ulagashev). Gorno-Altaisk: "Gorno-Altaisk knizhnoe izdatel'stvo" Publ. (in Russian).

Gordlevsky, V. A. 1962. In Izbrannye sochineniia. Istoriia i kul'tura (Selected Works. History and Culture) 3. Moscow: "Vostochnaia literatura" Publ., 299-325 (in Russian).

Zuev, Yu. A. 1967. Drevnetiurkskie genealogicheskie predaniia kak istochnik po rannei istorii tiurkov (Ancient Turkic Genealogical Legends as a Source on the Early History of the Turks). Diss. of Candidate of Historical Sciences. Alma-Ata (in Russian).

Ivanov, V. V. 2012. In Rodionov, M. A. (ed.). Bestiarii II. Zoomorfizmy Azii: dvizhenie vo vremeni (Bestiary II. Zoomorphisms of Asia: Movement in Time). Saint Petersburg: Peter the Great Museum of Anthropology and Ethnography (the Kunstkamera), 91-98 (in Russian).

Ploskikh, V. M. 1984. (ed.-in-chief). Istoria Kirgizskoi SSR (History of the Kyrgyz Soviet Socialist Republic) 1. Frunze: Kyrgyzstan (in Russian).

Kiselev, S. V. 1949. In Materialy i issledovaniia po arkheologii SSSR (Materials and Research in the USSR Archaeology) 9. Leningrad: Academy of Sciences of the USSR (in Russian).

Korol, G. G. 2015. In Dashkovskiy, P. K. (ed). Mirovozzrenie naseleniia Yuzhnoi Sibiri i Tsentral'noi Azii $v$ istoricheskoi retrospective (Worldviews of the Population of Southern Siberia and Central Asia in Historical Retrospect) 8. Barnaul: Altay University Publ., 47-63 (in Russian).

Kuchukova, D. A. 2013. In Vestnik Tiumenskogo gosudarstvennogo universiteta (Bulletin of Tyumen State University) 2, 21-26 (in Russian).

Kychanov, E. I. 1997. Kochevye gosudarstva ot gunnov do man'chzhurov (Nomadic States from the Huns to the Manchus). Moscow: "Vostochnaia Literatura" Publ., Russian Academy of Sciences (in Russian). 
Lunina, S. B.1978. In Obel'chenko, O. V., Ovezov, D. M., Khodzhaniiazov, T. (eds.). Istoriia i arkheologiia Srednei Azii (History and Archaeology of Central Asia). Ashkhabad: "Ylym" Pub., 203-211 (in Russian).

Lewis, R. 2004. Osmanskaia Turtsiia. Byt. Religiia. Kul'tura (Osman Turkey. Everyday Life, Religion, Culture). Moscow: “Tsentrpoligraf" Publ. (in Russian).

Nurzhanov, A. A. 2016. In Baitanayev, B. A. (ed.). Kul'turnoe nasledie Evrazii (s drevnosti do nashikh dney) (Cultural Heritage of Eurasia (from Antiquity to Present Day)). Almaty: A. Kh. Margulan Institute of Archaeology, 410-438 (in Russian).

Nurzhanov, A. A. 2003. In Vestnik Kazakhskogo gosudarstvennogo universiteta imeni al'-Farabi. Seriia istoricheskaia (Bulletin of Al-Farabi Kazakh National University. Historical Series) 29 (3). 122-126 (in Russian).

Orus-ool, S. M. 2001. Tuvinskie geroicheskie skazaniia (tekstologiia, poetika, stil') (Tuvan Heroic Legends (Textual Study, Poetics, Style)). Moscow: "Maks Press" Publ. (in Russian).

Pugachenkova, G. N., Rempel, L. I. 1965. Istoriia iskusstv Uzbekistana s drevneishikh vremen do serediny XIX v. (Art History of Uzbekistan from Antiquity to the Mid-19't c.). Moscow: "Iskusstvo" Publ. (in Russian).

Radlov, V. V. 1989. Iz Sibiri (From Siberia). Moscow: "Nauka" Publ (in Russian).

Rempel, L. I. 1961. Arkhitekturnyi ornament Uzbekistana: istoriia razvitiia $i$ teoriia postroeniia (Architectural Ornament of Uzbekistan: Development History and Formation Theory). Tashkent (in Russian).

Rempel, L. I. 1989. In Pugachenkova, G. A. (ed.). Antichnye i rannesrednevekovye drevnosti iuzhnogo Uzbekistana. V svete novykh otkrytii Uzbekistanskoi iskusstvovedcheskoi ekspeditsii (Ancient and Early Medieval Antiquities of Southern Uzbekistan. In the Light of New Discoveries of the Uzbekistan Art Study Expedition). Tashkent: "Fan" Publ., 111-131 (in Russian).

Serebriakova, M. N. 1992. In Rodionov, M. A., Serebriakova, M. N. (eds.). Traditsionnoe mirovozzrenie narodov Perednei Azii (Traditional Worldview of the Peoples of Western Asia). Moscow: "Nauka" Publ., 61-94 (in Russian).

Serebriakova, M. N. 1980. In Zhukovskaya, N. L., Straganovich, G. G. (eds.). Simvolika kul'tov i ritualov narodov zarubezhnoi Azii (Symbols of Cults and Rituals of the Peoples of Foreign Asia). Moscow: "Nauka" Publ., 165-177 (in Russian).

Tolstov, S. P. 1935. Problemy istorii dokapitalisticheskikh obshchestv (Historical Issues of Pre-Capitalist Societies) (9-10), 3-41 (in Russian).

Tuchkova, N. A. 2005. In Gemuev, I. N., Molodin, V. I., Sokolova, Z. P. (ed.). Cult. Narody Zapadnoi Sibiri. Hanty. Mansi. Sel'kupy. Nentsy. Entsy. Nganasany. Kety (The people of Western Siberia. Khanty. Mansi. Selkups. Nenets. Enets. Nganasans. Chum). Moscow: "Nauka" Publ. 368-377 (in Russian).

Ulagashev, N. U. 1941. Altai-Buchai. Oirotskii narodnyi epos (Altai-Buchai. Oirot Folk Epos). Novosibirsk (in Russian).

Ushnitskii, V. V. 2016. In Problemy vostokovedeniia (The Issues of Oriental Studies). 73 (3), 30-35 (in Russian).

Shinzhin, I. B. 1997. Tropoi, prolozhennoi vekami: zhizn'i tvorchestvo skazitel'nitsy N.P. Chernoevoi (Trail laid by centuries: the life and work of narrator N.P. Chernoeva). Gorno-Altaisk (in Russian).

Araz, R. 1995. Harput'ta eski türk inançlart ve halk hekimliği. Ankara. (in Turkish).

Beydili, C. 2005. Türk Mitolojisi Ansiklopedik Sözlük. Ankara, 352-353 (in Turkish).

Erbek, M. 2002. Çatalhöyük'ten günümüze Anadolu motifleri. Ankara (in Turkish).

Kalafat, Y. 1995. Doğu Anadolu'da eski Türk inançlarının izleri. Ankara, 98 (in Turkish).

Yazıcı K. Kurt dede kavramının tarihi ve kültürümüz içindeki yeri. Available at: http:// www.gulenkoyu. com/forum/index.php?topic=2364.0; wap2 (accessed: 15.09.2011).

\section{About the Author:}

Nurzhanov Arnabay A. Candidate of Historical Sciences, Institute of Archaeology named after A. Kh. Margulan, Ministry of Education and Science of the Republic of Kazakhstan. Dostyk Ave., 44, Shevchenko Str., 28, Almaty, 050010, the Republic of Kazakhstan. 